\title{
EMILY BRONTË
}




\section{Women Writers}

General Editors: Eva Figes and Adele King

\section{Published titles:}

Margaret Atwood, Barbara Hill Rigney

Anne Brontë, Elizabeth Langland

Charlotte Brontë, Pauline Nestor

Emily Brontë, Lyn Pykett

Fanny Burney, Judy Simons

Willa Cather, Susie Thomas

Sylvia Plath, Susan Bassnett

Christina Stead, Diana Brydon

Eudora Welty, Louise Westling

Women in Romanticism, Meena Alexander

\section{Forthcoming:}

Fane Austen, Meenakshi Mukherjee

Elizabeth Barrett Browning, Marjorie Stone

Elizabeth Bowen, Phyllis Lassner

Ivy Compton Burnett, Kathy Gentile

Colette, Diana Holmes

Emily Dickinson, Joan Kirkby

George Eliot, Kristin Brady

Mrs Gaskell, Jane Spencer

Doris Lessing, Barbara Hill Rigney

Katherine Mansfield, Diane DeBell

Christina Rossetti, Linda Marshall

Jean Rhys, Carol Rumens

Stevie Smith, Catherine Civello

Muriel Spark, Judith Sproxton

Edith Wharton, Katherine Joslin

Virginia Woolf, Clare Hanson 


\title{
Women Writers
}

\section{Emily Brontë}

\author{
Lyn Pykett
}

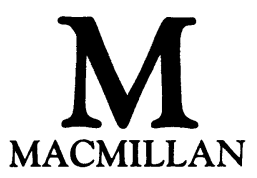


All rights reserved. No reproduction, copy or transmission of this publication may be made without written permission.

No paragraph of this publication may be reproduced, copied or transmitted save with written permission or in accordance with the provisions of the Copyright Act 1956 (as amended), or under the terms of any licence permitting limited copying issued by the Copyright Licensing Agency, 33-4 Alfred Place, London WC1E 7DP.

Any person who does any unauthorised act in relation to this publication may be liable to criminal prosecution and civil claims for damages.

First published 1989

Published by

MACMILLAN EDUCATION LTD

Houndmills, Basingstoke, Hampshire RG21 2XS

and London

Companies and representatives

throughout the world

British Library Cataloguing in Publication Data

Pykett, Lyn, 1947-

Emily Brontë.-(Women writers)

1. Poetry in English. Brontë, Emily,

1818-1848-Critical studies

2. Fiction in English. Brontë, Emily,

1818-1848-Critical studies

I. Title II. Series

$821^{\prime} .8$

ISBN 978-0-333-44605-8 ISBN 978-1-349-20401-4 (eBook)

DOI 10.1007/978-1-349-20401-4 


\section{Contents}

Acknowledgements vi

Editors' Preface vii

1. Emily Brontë: A Life Hidden From History 1

2. The Writings of Ellis Bell 18

3. 'Not at all like the poetry women generally write': the Problem of the Woman Poet 36

4. Death Dreams and Prison Songs 48

5. Gender and Genre in Wuthering Heights: Gothic Plot and Domestic Fiction 71

6. Changing the Names: the Two Catherines 86

7. Nelly Dean: Memoirs of a Survivor 99

8. The Male Part of the Poem 109

9. Reading Women's Writing: Emily Brontë and Critics

Notes

135

$\begin{array}{ll}\text { Bibliography } & 140\end{array}$

$\begin{array}{ll}\text { Index } & 144\end{array}$ 


\section{Acknowledgements}

I would like to thank members of the Northern Network group who helped me to clarify some of the ideas in Chapter 5. Particular thanks to the women members of the English Department of the University of Leeds for their hospitality on this occasion. Thanks are also due to staff and students of the English Departments at Aberystwyth and Swansea, who probably got more of Emily Brontë's poetry than they had expected at a colloquium on nineteenth-century women writers at Gregynog. My greatest debt is to my husband, who neither ironed my shirts, nor typed up the fruits of my labours, but who took on much more than his fair share of childcare, and left me to my own (de)vices. 


\section{Editors' Preface}

The study of women's writing has been long neglected by a male critical establishment both in academic circles and beyond. As a result, many women writers have either been unfairly neglected, or have been marginalised in some way, so that their true influence and importance has been ignored. Other women writers have been accepted by male critics and academics, but on terms which seem, to many women readers of this generation, to be false or simplistic. In the past the internal conflicts involved in being a woman in a male-dominated society have been largely ignored by readers of both sexes, and this has affected our reading of women's work. The time has come for a serious re-assessment of women's writing in the light of what we understand today

This series is designed to help in that re-assessment. All the books are written by women, because we believe that men's understanding of feminist critique is only, at best, partial. And besides, men have held the floor quite long enough.

Eva Figes

Adele King 